\title{
THE ACTION OF ARSENIC ON THE BONE MARROW OF MAN AND ANIMALS.
}

\author{
By Ralpu Stockian, M.D., and Francis J. Chaliteris, M.B., Ch.B., \\ University of Glasgow.
}

\section{(Plate XXI.)}

THE action of arsenic on the bone marrow is of great therapeutical interest, in view of its extensive employment as a "blood tonic" in all kinds of anæmic conditions; and of pathological interest, in view of the anatomical changes in the marrow and of the anæmia which result from chronic arsenical poisoning. Small doses of arsenic carefully administered improve general nutrition and encourage an increase of body fat, while they are supposed also to stimulate the activity of the bone marrow in forming new blood corpuscles; but, on the other hand, quantities sufficient to cause chronic poisoning are known to produce general emaciation, and an interference with the nutrition of the tissues in which the bone marrow and blood are both involved. The exact significance of the changes in the bone marrow and the extent to which these are peculiar to the action of arsenic have not hitherto been explained, owing chiefly to want of the data necessary for forming an opinion. The number of researches on the subject is not large, and with one exception these have hitherto been concerned with observing the effects experimentally produced in animals. The recent epidemic of arsenical poisoning from contaminated beer in Manchester has afforded an opportunity of examining the bone marrow in a number of fatal cases, and we are much indebted to Dr. F. Craven Moore, pathologist to the Manchester Royal Infirmary, who took a great deal of trouble in supplying us with the necessary material, consisting of portions of vertebræ, ribs, and long bones. While we were engaged in examining these, Dr. J. C. Muir (1) published a paper on "The Condition of the Blood and Marrow in Chronic Arsenical Poisoning, with special reference to Cutaneous Pigmentation," and he has very kindly sent us some of his specimens to compare with our own. Dr. Muir's research was chiefly concerned with the question of the relation between the pigments of the blood and of the skin, but he also gives a description of the changes in the bone marrow, and says that: "Briefly summed up, the cases show a very decided erythroblastic reaction, and a less

30 一L. OF PATH.-VOL. vili. 
marked leucoblastic one," added to which is a greater or less amount of hyaline degeneration.

Before describing the changes which we found in human marrow, we wish to refer at some length to those which occur in the marrow of animals under the action of arsenic. These have been investigated by Raimondi ( $\left.{ }^{2}\right)$ and by Bettmann ( $\left.{ }^{3}\right)$ in rabbits, and by Stockman and Greig $\left(^{4}\right)$ in rabbits and young dogs, all of whom agree that the fat cells atrophy, that the capillary blood vessels become much dilated and more numerous, and that the cells also become much more numerous. The changes are very prominent and striking, and are figured in the paper by the last-named authors. The opinion is expressed by Raimondi and by Bettmann, that it is the erythroblastic cells which so greatly increase in number; while Stockman and Greig thought that the histological changes point to a stimulation of the marrow and an increased production of red corpuscles. Since then, however, we have examined the action of lead, phosphorus, mercury, and other substances on the marrow, and have found that their effects are somewhat similar to those of arsenic, while papers published in the interval by Milroy and Malcolm ( $\left.{ }^{5}\right)$, Roger and Josué $\left({ }^{6}\right)$, Haushalter and Spillmann $\left({ }^{7}\right)$, Robert Muir $\left(^{8}\right)$, and others, show that nucleic acid, phosphorus, various organisms and toxines, liver extracts, peptones, and other bodies, are capable of producing the same kind of changes as arsenic does.

After hæmorrhage and in pernicious anæmia the bone marrow loses its fat to a great extent, becomes more vascular, and shows an increase in its cellular elements. The increase, however, is of the "erythroblastic" type, that is, in the number of the cells which produce red blood corpuscles, and is clearly due to increased activity on the part of these cells, the outcome of an attempt to supply the deficiency of red corpuscles in the blood. Under the action of arsenic, of various toxines and infective organisms, and of the other foreign substances already alluded to, the increase in the cellular elements of the bone marrow is equally marked, but it is of the "leucoblastic" type, that is, an increase chiefly of the marrow cells ("neutrophile myelocytes" of Ehrlich) which produce the finely granular polymorpho-nuclear leucocytes, and it corresponds to an attempt to deal with the poison by means of an increased flow of leucocytes into the blood. It is, in short, protective in character as regards the organism, and destructive as regards the poison. This leucoblastic reaction has been discussed at length by Roger and Josué $\left({ }^{9}\right)$, and by Robert Muir $\left({ }^{8}\right)$, and to their papers we must refer for fuller particulars. At the beginning the number of erythroblast cells may undergo a slight increase, but it amounts to very little.

We may summarise the changes seen in the bone marrow of rabbits and dogs under small doses of arsenic, as follows. There occur hyperæmia, atrophy of fat cells, decrease in number or degeneration of 
giant cells, increase of the leucoblastic cells, little or no increase in the number of the erythroblastic cells of the marrow. These changes do not indicate increased activity in the direction of the formation of red blood corpuscles, but rather point to an increased production of the finely granular leucocytes of the blood. In none of our animals was there any trace of hyaline degeneration of the marrow, probably because none of them suffered from emaciation or cachexia. These effects on the marrow are essentially similar to those produced under the action of many other foreign or poisonous substances, and they constitute a reaction against these substances on the part of the body.

The result of counting the blood corpuscles and estimating the hremoglobin in animals or man receiving arsenic supports the idea that there is no increase in the number or quality of the red cells circulating in the blood. In rabbits, Raimondi found a decrease in their number, which ultimately became extreme; Stockman and Greig, with small doses, saw no alteration; Bettmann alone got an increase with small doses, but a distinct decrease with larger amounts. In man, many authors-Cutler and Bradford $\left({ }^{10}\right)$, Delpeuch $\left({ }^{11}\right)$, Malcolm Morris $\left({ }^{12}\right)$, Almkvist and Welander $\left({ }^{13}\right)$, Stierlin $\left({ }^{14}\right)$-have reported a diminution of red blood corpuscles and hæmoglobin under the action of therapeutic doses of arsenic. In chlorosis, Stockman $\left({ }^{15}\right)$ found no change in the blood when arsenic in small doses was alone given, while in chorea, heart disease, and other conditions, it neither increases nor diminishes the red corpuscles and hæmoglobin. In malaria and in pernicious anæmia its hæmatinic action is probably due to destruction of corpuscledestroying parasites.

As regards the Manchester epidemic, the hæmoglobin and corpuscles have been reported as diminished, with a slight increase in the leucocytes; J. C. Muir's observations give no light on this point as they were made long after the ingestion of arsenic had been stopped, and showed considerable variation in the results. The evidence seems conclusive that, apart from its action in certain diseases, arsenic does not increase, and often diminishes the number of red corpuscles in the blood of man and animals; and this we think confirms our opinion that the marrow change is essentially leucoblastic and not erythroblastic in its character. We now come to a description of the changes in the bone marrow of man as found in several cases of chronic arsenical poisoning. These changes may be slight, consisting merely in some increase of the blood vessels and marrow cells, with a trifling diminution in the amount of fat. In photograph 2 (Plate XXI.), however, a much altered bone marrow is shown. In this the fat cells have almost entirely disappeared, and the space thus left is occupied by leucoblastic cells, which are greatly increased in number. The erythroblast cells are also more numerous than usual, but not to any great extent, the change being essentially leucoblastic in character. The capillary vessels are increased 
in number, but the photograph scarcely shows this. The condition is similar to what has been found in rabbits and dogs. In Plate XXI. Fig. 3 the atrophy of the fat cells is not so marked, and hyaline degeneration is present. (The section was focussed with the object of showing the distended capillaries filled with red blood corpuscles, and these are prominent, while the marrow cells are very indistinct.) Plate XXI. Figs. 4 and 5 show marked hyaline degeneration of the marrow, with great diminution in the number of marrow cells, and practically no atrophy of the fat cells. It is seldom that the whole marrow of a bone is equally degenerated, the changes being usually distributed in a patchy manner, some parts being very much worse than others. When the hyaline degeneration becomes marked, the cells of the marrow diminish greatly in number, and this we believe affords an explanation of the diminution of blood corpuscles and of the anæmia in advanced cases. These extreme degrees of hyaline degeneration are, however, not peculiar to arsenic poisoning. They occur in other chronic poisonings and in many chronic diseases, such as phthisis, carcinoma, dysentery, and other marasmic or cachectic states. Many of the fatal cases in the Manchester epidemic died of phthisis, and wasting and cachexia are prominent symptoms of severe chronic arsenical poisoning; hence it is impossible to say how far the changes depend on the direct action of arsenic, and how far on the general cachexia and phthisis which follow in its wake.

In conclusion, we are of opinion that neither the early nor the late pathological changes in the bone marrow are peculiar to arsenic, seeing that they occur with other poisons and in many diseases. The marrow seems to react similarly to many different toxic agents.

\section{Summary.}

1. In small repeated doses arsenic acts on the bone marrow, causing increase in the number of leucoblastic cells, little or no change in the number of erythroblastic cells, marked hyperæmia, and atrophy of fat cells.

2. During this stage there is no increase in the red corpuscles or hemoglobin of the blood.

3 . In repeated doses, large enough to cause cachexia and emaciation, the bone marrow undergoes hyaline degeneration.

4. This is accompanied by decrease of the red corpuscles and hæmoglobin of the blood.

5. All these changes occur with other drugs and poisons, and are not peculiar to arsenic.

6. Arsenic has no direct effect in increasing the production of red blood corpuscles by the bone marrow.

7. The "hrematinic" action of arsenic in pernicious anæmia, malaria, lymphadenoma, leukæmia, and some other diseases, probably 


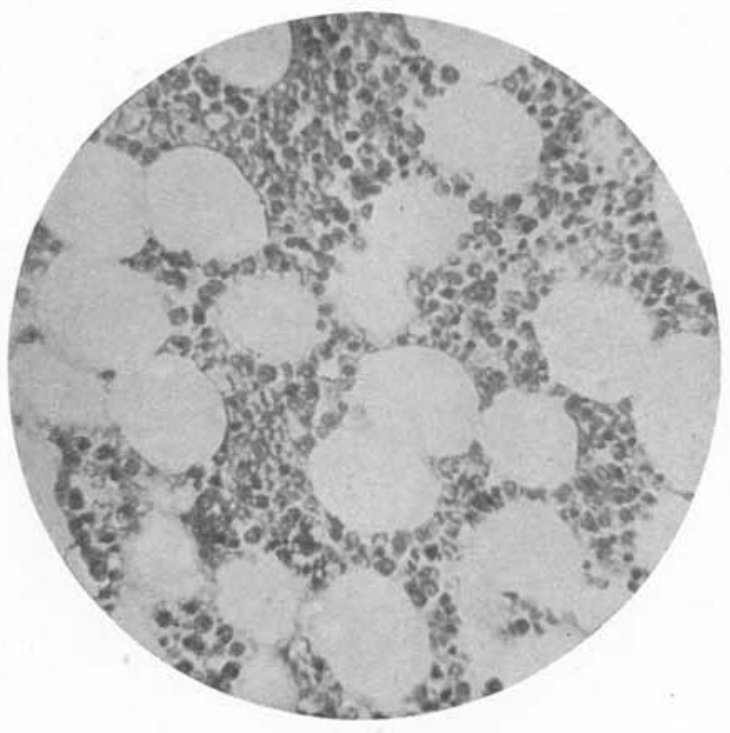

Fig. 1.

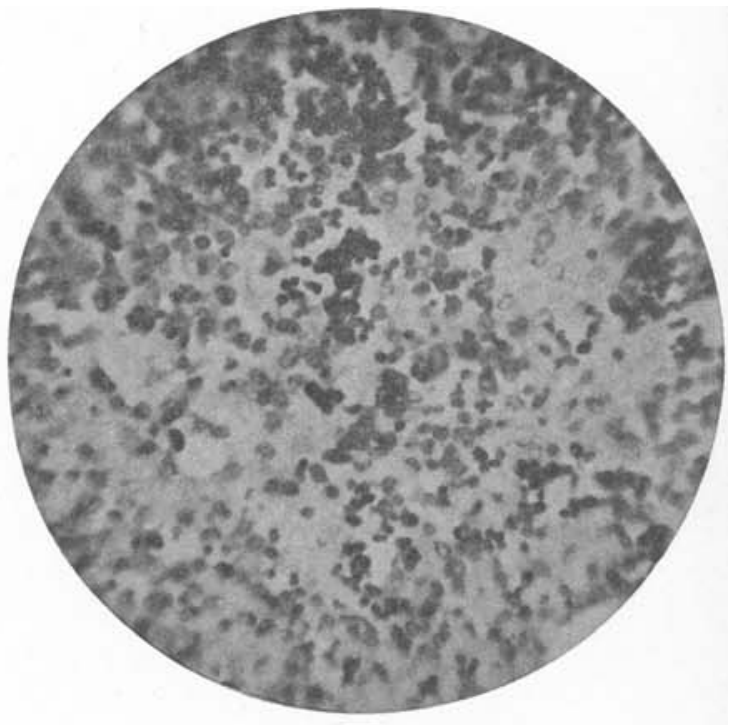

Fig. 2.

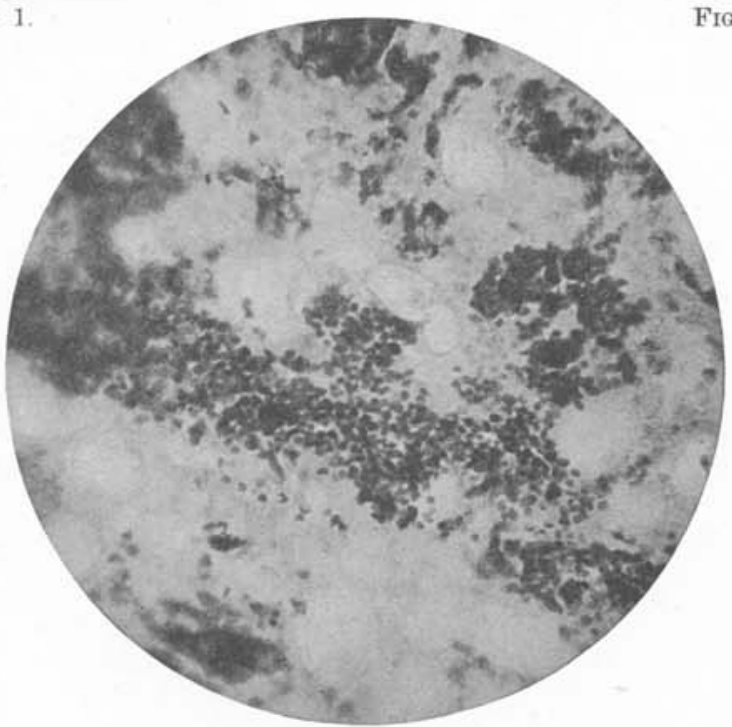

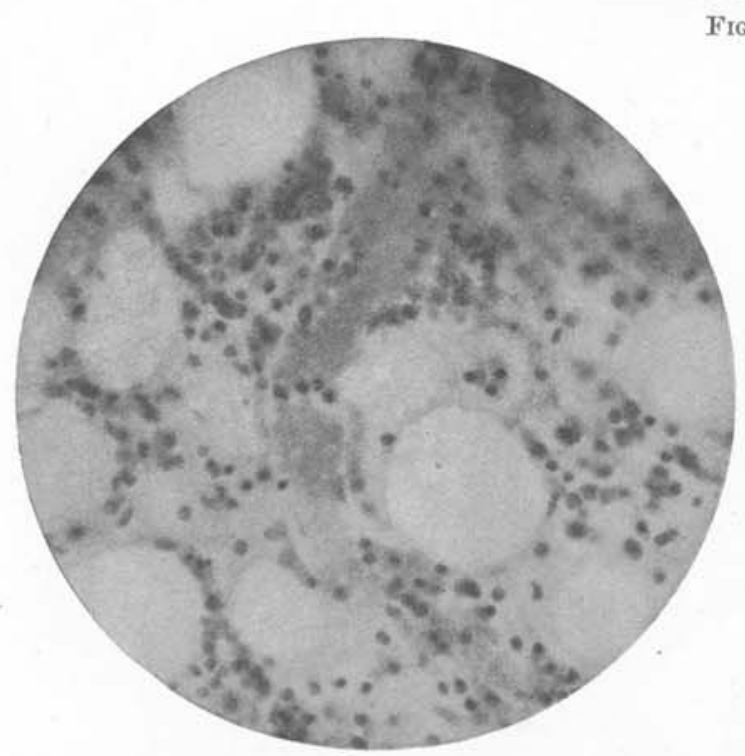

Fig. 4.

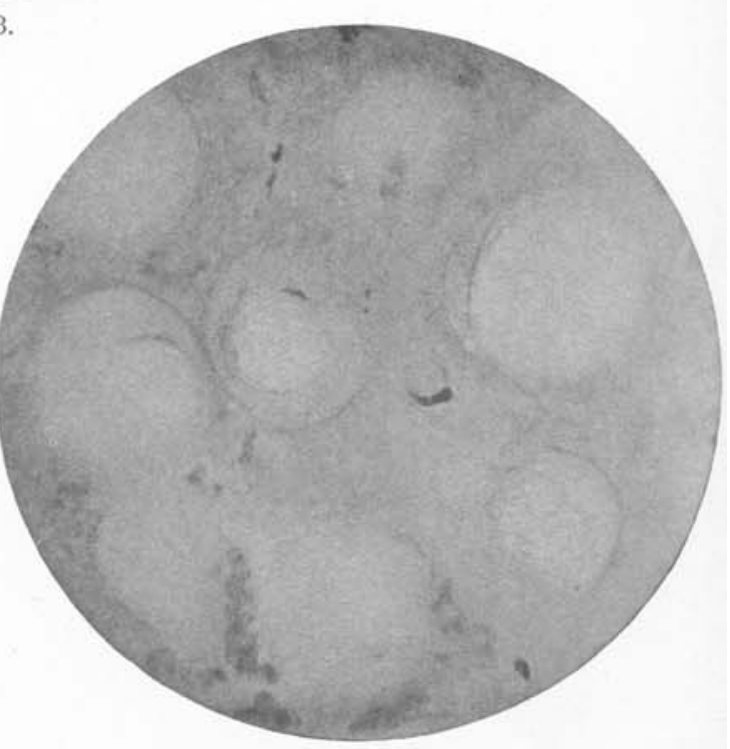

Fig. 5 . 
results from a specific action on the parasites which cause these diseases, and not from any direct action on blood formation.

\section{REFERENCES.}

1. Murr, J. C. . . . . . Journ. Path. and Bacteriol., Edin. and London, 1901, vol. vii. p. 420 .

2. Raimond . . . . . . Ann. univ. di med. e chir., Milano, 1880, tomo ccli. p. 52.

3. Bettmann. . . . . . Beitr. z. path. Anat. u. z. allg. Path., Jena, 1898, Bd. xxiii. S. 377.

4. Stockman and Greig . Journ. Physiol., Cambridge and London, 1898, vol. xxiii. p. 376.

5. Milroy and Malcoly - Ilidi., 1899, vol. xxv. p. 103.

6. Roger and Josut . . . Compt. rend. Soc. de biol., Paris, 1899.

7. Haushalter and Spili- Ilirl., 1899. MANN.

8. Muir, Robert . . . . Journ. Path. amul Bacteriol., Edin. and London, 1901, vol. vii. p. 161, and Trans. Path. Soc. London, 1902, vol. liii. p. 379.

9. Roger and Josur . . . La moelle osseuse, Paris, 1899.

10. Cutler and Bradford . Am. Journ. Med. Sc., Phila., 1878, vol. lxxv. p. 74.

11. Delpeuch . . . . . Thèse de Paris, 1880.

12. Morris . . . . . . Practitioner, London, 1880 , vol. xxv. p. 8.

13. Almkvist and Welander Brit. Med. Journ., London, Epitome 1901, vol. i. p. 28.

14. Stierlin . . . . . . Deutsches Arch. f. Mlin. Med., Leipzig, 1889, Bd. xlv. S. 279 .

15. Stockman . . . . . Brit. Med. Journ., London, 1893, vol. i. p. 881.

\section{DESCRIPTION OF PLATE XXI.}

Fuf. 1.-Norma! human bone marrow from rib.

FIs. 2.-Early action of arsenic. Shows great increase of the cells of the marrow, and disappearance of fat cells.

FIo. 3.-More advanced. Shows hyaline degeneration, great diminution in the number of cells, some atrophy of fat cells, and increase in number and size of blood vessels.

Firss. 4, 5.-Varying degrees of marked hyaline degeneration, with disappearance of the normal marrow tissue.

The magnification is not exactly the same in all, but is approximately abont 250 dianeters. 